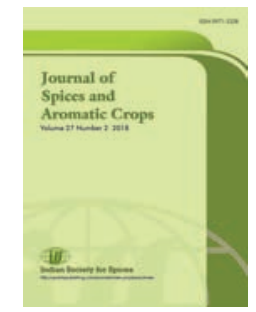

\title{
Comparison of quality of dry turmeric (Curcuma longa) produced by slicing and other curing methods
}

E Jayashree*, T J Zachariah \& R Rakhi

ICAR-Indian Institute of Spices Research, Kozhikode-673 012, Kerala.

${ }^{*}$ E-mail: jayasree@spices.res.in

Received 03 April 2018; Revised 30 June 2018; Accepted 25 October 2018

\begin{abstract}
The study determines the effect of slicing and curing turmeric (var. Alleppey Supreme) on the quality of dry turmeric rhizomes produced. The turmeric rhizomes were sliced to $5 \mathrm{~mm}$ and the curing methods followed were steam curing in TNAU model turmeric boiler for $60 \mathrm{~min}$ and traditional water boiling for $60 \mathrm{~min}$. The drying characteristics curves obtained indicated that the time required for drying was significantly reduced by slicing to $127 \mathrm{~h}$ ( 5 days) and the maximum time of $288 \mathrm{~h}$ (12 days) was required for complete drying of steam cured turmeric in TNAU boiler. Quality analysis of the dried turmeric samples indicated that the maximum retention of primary metabolites i.e. carbohydrates, proteins, fat and starch was found in turmeric samples cured by water boiling method for 60 min corresponding to 53.15, 3.16, 2.72 and 49.14\%, respectively and the maximum retention of secondary metabolites i.e. essential oil, oleoresin and curcumin content were observed in sliced samples and the values corresponded to $6.23,10.51$ and $3.74 \%$, respectively.
\end{abstract}

Keywords: curing, slicing, steam curing, quality, water boiling

\section{Introduction}

Turmeric (Curcuma longa), is an important spice in Indian foods with medicinal properties. It is a member of the Zingiberaceae family, and consists of about 110 species, distributed in tropical Asia and the Asia-Pacific region. Fresh rootstock has an aromatic and spicy fragrance, which on drying generates a peculiar medicinal aroma. India is the largest producer, consumer and exporter of turmeric in the world. The production of turmeric in India during 2013-2014 was 5.8 million tonnes from an area of 3.17 million hectares (Spices Board, 2017a). During 2015-16, a total volume of 88,500 tonnes of turmeric valued 921.65 crores was exported as against 86,000 tonnes valued 744.35 crores during 201415 (Spices Board, 2017b).

Turmeric is mostly used as a condiment and a small quantity is used in pharmaceuticals and cosmetics. Turmeric possesses a great variety of pharmacological activities and these include its anti-inflammatory, antioxidant, antibacterial, 
antifungal, antiviral, antimutagenic, anticarcinogenic, anticoagulant, antidiabetic, antifibrotic, antivenom, antiulcer, and hypocholesteremic activities (Braga et al. 2003, Chattopadhyay et al. 2004).

Curing of turmeric, is an important post harvest processing operation and the process involves cooking of the rhizomes fresh turmeric in boiling water for approximately about 60 minutes and is an essential operation to be done before drying. Curing in boiling water avoids the raw odour, destroys the vitality of fresh rhizomes, yields uniformly coloured product and reduces the drying time. The objective of this experiment was to study the effect of slicing over curing of turmeric on the quality of dry turmeric obtained.

\section{Materials and methods}

Turmeric (var. Alleppey Supreme) was obtained from ICAR-Indian Institute of Spices Research (ICAR-IISR), Experimental Farm, Peruvannamuzhi, Kozhikode, Kerala and the experiment was conducted during May 2017 to determine the effect of curing slicing on the quality of dried turmeric rhizomes. Fresh turmeric rhizomes $(25 \mathrm{~kg})$ were washed thoroughly to remove the surface impurities and cured by traditional water boiling method for $60 \mathrm{~min}$ and another set was steam cooked for 60 min in TNAU turmeric boiler (Viswanathan et al. 2002). Another set of washed turmeric rhizomes were sliced manually to a thickness 5 $\mathrm{mm}$ and then dried. All the turmeric samples were dried on the roof top concrete floor of ICAR-IISR main building. The weather parameters were recorded during the month of May 2017 and the mean monthly weather conditions for the particular month was calculated. The experiments were carried between 9:00 and 17:00 $\mathrm{h}$. The temperature and relative humidity of ambient air were measured using a digital temperature and relative humidity meter (EQUINOX, EQ-321 S) and the solar radiation was measured using TES1332A model digital lux meter. The weather parameters were recorded at $1 \mathrm{~h}$ interval and drying was continued till constant weight was obtained.

The cured turmeric was analyzed for its biochemical qualities in terms of its primary and secondary metabolites. Primary metabolites analyzed were carbohydrate, fat, protein and starch (Sadasivam \& Manickam 2008). Secondary metabolites estimated were essential oil, oleoresin and curcumin content. Essential oil was determined by reflux distillation method and oleoresin content was determined by solvent extraction method both as per the procedure described in ASTA (1997) and curcumin was quantitatively extracted by refluxing the material in acetone and estimated spectrophotometrically at $425 \mathrm{~nm}$ (ASTA 1968). Moisture content of the fresh samples was determined by toluene distillation method (ASTA 1997). The essential oil samples collected were analyzed using a gas chromatograph (Shimadzu GC 2010) equipped with mass spectroscope (Shimadzu QP-2010) and capillary column (RTX-Wax, 30m $\times 0.25 \mathrm{~mm}$ id $\times$ $0.25 \mathrm{im})$. The column temperature was programmed as (Injection port temperature: 250UC, flow rate: $1 \mathrm{~mL} \mathrm{~min}^{-1}$, carrier gas: helium with linear velocity of $48.1 \mathrm{~cm} / \mathrm{s}$, Split ratio: 50, Ionization energy: $70 \mathrm{eV}$, Mass range: 40-650 amu). Statistical analysis of quality parameters were done by AGRES (Version 7.01, Pascal Intl software solutions) statistical software.

\section{Results and discussions}

The average temperature on the concrete floor of the roof top varied from a minimum of $38.25^{\circ} \mathrm{C}$ at $9.00 \mathrm{~h}$ to a maximum of $52.31^{\circ} \mathrm{C}$ at $12.00 \mathrm{~h}$. The average relative humidity varied from $48.95 \%$ at $9.00 \mathrm{~h}$ to $61.32 \%$ at $17.00 \mathrm{~h}$.

\section{Drying characteristics}

The drying characteristics curves (Fig. 1) of sliced rhizomes, turmeric rhizomes cured by steam in TNAU turmeric boiler for $60 \mathrm{~min}$ and by traditional water boiling method for $60 \mathrm{~min}$, followed by sun drying of all the samples, indicated that during drying the moisture content decreased continuously. The drying time reduced significantly to $127 \mathrm{~h}$ (5 days), when the rhizomes were sliced to $5 \mathrm{~mm}$ thick and dried. The moisture content of turmeric rhizomes cured by water boiling method decreased from an initial moisture content of $418.96 \%$ dry basis (d.b) to final moisture of $11.41 \%$ (d.b) and it took $240 \mathrm{~h}$ (10 days) for complete drying. While turmeric rhizomes steam cured in TNAU turmeric boiler for 60 min took maximum time of $288 \mathrm{~h}$ (12 days) for complete drying. The drying rate was faster 
for sliced turmeric samples and corresponded to $0.57 \mathrm{~kg}$ per $\mathrm{kg}$ of dry matter per hour.

Borah et al. (2015) carried out drying of turmeric in a solar conduction dryer. The temperature of drying air achieved was around $39-51^{\circ} \mathrm{C}$ for an ambient temperature in the range of $25-28^{\circ} \mathrm{C}$. The experiment revealed that in $12 \mathrm{~h}$ of effective drying time, the moisture content reduced from $78.65 \%$ wet basis (w.b) to $6.36 \%$ (w.b) for whole turmeric samples and to $5.50 \%$ (w.b) for sliced turmeric samples. The study also indicated that drying curve of sliced samples showed more uniform falling rate in comparison to that of whole samples.

\section{Physical properties of dried rhizomes}

The dry recovery of turmeric rhizomes varied from a minimum of $20.80 \%$ for sliced turmeric to a maximum of $22.20 \%$ for traditional water boiled turmeric with corresponding moisture content of 9.24 and $9.86 \%$, respectively (Table 1 ). The analysis of variance indicated $(p<0.05)$ that the there was no significant variation in the dry recovery of turmeric sample obtained by different treatment methods.

Lokhande et al. (2013) studied the effect of curing and drying methods on dry recovery of three turmeric cultivars Salem, Krishna and Tekurpetha and revealed that there was no significant difference between cured and uncured turmeric samples for all the three cultivars. However, the samples dried under shade-net were having higher dry recovery than other drying methods like sun drying and mechanical drying for all the three cultivars studied.

\section{Variation in primary metabolites}

The variation in primary metabolites of sliced samples in comparison to cured samples indicated that maximum availability of carbohydrates, proteins, fat and starch was found in turmeric samples cured by water boiling method corresponding to $53.15,3.16,2.72$ and $49.14 \%$, respectively (Table 2). This was followed by steam cured turmeric samples in TNAU boiler with values corresponding to $48.82,3.15,2.63$ and $42.69 \%$, respectively showing significant reduction in carbohydrate, starch and fat content. Lowest values of primary metabolites were observed in sliced samples and the analysis of variance showed that there was significant reduction $(p<0.05)$ in the carbohydrate, fat and starch content of sliced turmeric samples and the values corresponded to $42.14,2.12$ and $40.80 \%$, respectively. However, the variation in protein content was nonsignificant.

Dried turmeric rhizomes showed average composition of $69.4 \%$ of carbohydrates, $13.1 \%$ of water; $6.3 \%$ of proteins, $5.1 \%$ of fats, $3.5 \%$ of ash,

Table 1. Variation in physical properties and primary metabolites of sliced and cured turmeric

\begin{tabular}{|c|c|c|c|c|c|c|c|}
\hline \multirow[t]{2}{*}{ Treatment } & \multicolumn{3}{|c|}{ Physical properties } & \multicolumn{4}{|c|}{ Primary metabolites } \\
\hline & $\begin{array}{l}\text { Drying } \\
\text { time } \\
\text { (h) }\end{array}$ & $\begin{array}{l}\text { Dry } \\
\text { recovery } \\
(\%)\end{array}$ & $\begin{array}{l}\text { Moisture } \\
\text { content } \\
(\%)\end{array}$ & $\begin{array}{c}\text { Carbohydrate } \\
\qquad(\%)\end{array}$ & $\begin{array}{l}\text { Protein } \\
\qquad(\%)\end{array}$ & $\begin{array}{l}\text { Fat } \\
(\%)\end{array}$ & $\begin{array}{l}\text { Starch } \\
\text { (\%) }\end{array}$ \\
\hline $\begin{array}{l}\text { T1 - Sliced turmeric } \\
\text { rhizomes } 5 \mathrm{~mm} \\
\text { thick }\end{array}$ & $\begin{array}{c}127 \\
\text { (5 days) }\end{array}$ & $20.80^{c}$ & $9.24^{c}$ & $42.14^{c}$ & $3.13^{c}$ & $2.12^{b}$ & $40.80^{c}$ \\
\hline $\begin{array}{l}\text { T2 - Turmeric rhizom } \\
\text { steam cured in TNAU } \\
\text { boiler for } 60 \mathrm{~min}\end{array}$ & $\begin{array}{l}288 \\
\text { (12 days) }\end{array}$ & $21.4^{\mathrm{b}}$ & $9.73^{b}$ & $48.82^{b}$ & $3.15^{\mathrm{b}}$ & $2.63^{\mathrm{a}}$ & 42.69 \\
\hline $\begin{array}{l}\text { T3 - Turmeric rhizom } \\
\text { cured by traditional } \\
\text { water boiling for } \\
60 \text { min }\end{array}$ & $\begin{array}{l}\text { les } \\
240 \\
\text { (10 days) }\end{array}$ & $22.2^{\mathrm{a}}$ & $9.86^{\mathrm{a}}$ & $53.15^{\mathrm{a}}$ & $3.16^{\mathrm{a}}$ & $2.72^{\mathrm{a}}$ & $49.14^{\mathrm{a}}$ \\
\hline SED & & 0.81 & 0.03 & 0.06 & 0.70 & 0.07 & 0.27 \\
\hline $\mathrm{CD}(0.05)$ & & NS & $0.07^{*}$ & $0.14^{*}$ & $1.72^{\mathrm{NS}}$ & $0.17^{*}$ & $0.66^{*}$ \\
\hline
\end{tabular}


Table 2. Variation in secondary metabolites of sliced and cured turmeric

\begin{tabular}{lcccccccc}
\hline & \multicolumn{3}{c}{ Secondary metabolites } & \multicolumn{3}{c}{ Essential oil constituents } \\
\cline { 2 - 9 } Treatment & $\begin{array}{c}\text { Essen- } \\
\text { tial } \\
\text { oil } \\
(\%)\end{array}$ & $\begin{array}{c}\text { Oleo- } \\
\text { resin }\end{array}$ & $\begin{array}{c}\text { Cur- } \\
\text { cumin }\end{array}$ & $\begin{array}{c}\beta \text {-ses- } \\
\text { quiphell- } \\
\text { andrene } \\
(\%)\end{array}$ & $\begin{array}{c}\text { ar- } \\
\text { curcu- } \\
\text { mene } \\
(\%)\end{array}$ & $\begin{array}{c}\text { tur- } \\
\text { mer- } \\
\text { one } \\
(\%)\end{array}$ & $\begin{array}{c}\text { ar- } \\
\text { turmer- } \\
\text { one } \\
(\%)\end{array}$ & $\begin{array}{c}\alpha- \\
\text { phellan- } \\
\text { drene } \\
(\%)\end{array}$ \\
\hline $\begin{array}{l}\text { T1 - Sliced turmeric rhizomes } \\
5 \text { mm thick }\end{array}$ & $6.2^{\mathrm{a}}$ & $10.51^{\mathrm{a}}$ & $3.74^{\mathrm{a}}$ & $2.58^{\mathrm{c}}$ & $1.37^{\mathrm{a}}$ & $0.98^{\mathrm{c}}$ & $43.75^{\mathrm{a}}$ & $2.48^{\mathrm{c}}$ \\
$\begin{array}{l}\text { T2 - Turmeric rhizome steam } \\
\text { cured in TNAU boiler for } 60 \text { min }\end{array}$ & $5.73^{\mathrm{b}}$ & $10.26^{\mathrm{c}}$ & $3.52^{\mathrm{c}}$ & $3.14^{\mathrm{b}}$ & $1.13^{\mathrm{c}}$ & $1.06^{\mathrm{b}}$ & $41.71^{\mathrm{c}}$ & $3.60^{\mathrm{b}}$ \\
$\begin{array}{l}\text { T3 - Turmeric rhizomes cured by } \\
\text { traditional water boiling for }\end{array}$ & & & & & & & & \\
$\begin{array}{l}60 \text { min } \\
\text { SED }\end{array}$ & $5.87^{\mathrm{b}}$ & $10.35^{\mathrm{b}}$ & $3.65^{\mathrm{b}}$ & $3.33^{\mathrm{a}}$ & $1.15^{\mathrm{b}}$ & $1.80^{\mathrm{a}}$ & $42.82^{\mathrm{b}}$ & $3.75^{\mathrm{a}}$ \\
$\mathrm{CD}(0.05)$ & 0.09 & 0.67 & 0.008 & 0.81 & 0.82 & 0.50 & 0.81 & 0.81 \\
\hline
\end{tabular}

$2.6 \%$ of fibers and the curcuminoids content varied between 2 and $9 \%$, depending on geographic conditions (Esatbeyoglu et al. 2012).

\section{Variation in secondary metabolites}

Variation in secondary metabolites of sliced samples in comparison to cured turmeric samples indicated that maximum retention of secondary metabolites was observed in sliced samples. The essential oil, oleoresin and curcumin content of the sliced turmeric were $6.23,10.51$ and $3.74 \%$, respectively (Table 3 ). Analysis of variance indicated that there was significant reduction in the secondary metabolites of turmeric samples cured by water boiling method with values of essential oil, oleoresin and curcumin content varying as $5.87,10.35$ and $3.65 \%$, respectively and the lowest values were obtained for turmeric samples steam cured in TNAU boiler with values corresponding to 5.73, 10.26 and $3.53 \%$, respectively.

Gounder \& Lingamallu (2012) reported that the yield of volatile oil obtained (on a dry weight basis) for fresh, dried and cured turmeric rhizomes were $3.52 \pm 0.23,3.05 \pm 0.15$ and $4.45 \pm$ $0.37 \%$, respectively. However, the yield of volatile oil obtained from cured rhizome was $26 \%$ higher than that of fresh and $46 \%$ higher than that of dried samples. This may be due to the variation in curing and drying methods. In case of cured sample, the rhizomes were cooked in boiling water and dried in shade. There is no much damage to oil cells and the oil loss during drying process is reduced. Govindarajan \& Stahl (1980), reported that during the process of curing turmeric, the starch granules get gelatinized due to thermal processing and this facilitates uniform drying. Further, the rhizomes show volume expansion during cooking due to gelatinization of starch present in them and the volume of cooked rhizome is more than that of uncooked turmeric samples. The cured samples are easy to grind and the extractability of oil is more, when compared to the uncured sample. Asekun et al. (2007) reported that the method of drying had a significant effect on the quality and quantity of the volatile oils obtained.

Suresh et al. (2007) examined the loss of active ingredient curcumin during heat processing of turmeric by subjecting fresh turmeric to various cooking levels and found that curcumin loss from heat processing of turmeric was $27-53 \%$ with maximum loss during pressure cooking for 10 $\min$.

Prathapan et al. (2009) examined the effect of heat treatment on curcuminoid content of fresh turmeric rhizome. The rhizomes of fresh turmeric were subjected to heat treatment at different temperatures varying from 60 to $100^{\circ} \mathrm{C}$ for durations varying from 10 to $60 \mathrm{~min}$ and the quantification of curcuminoids was made using high performance thin layer chromatography (HPTLC). The studies indicated that there was no significant difference in the concentration of 


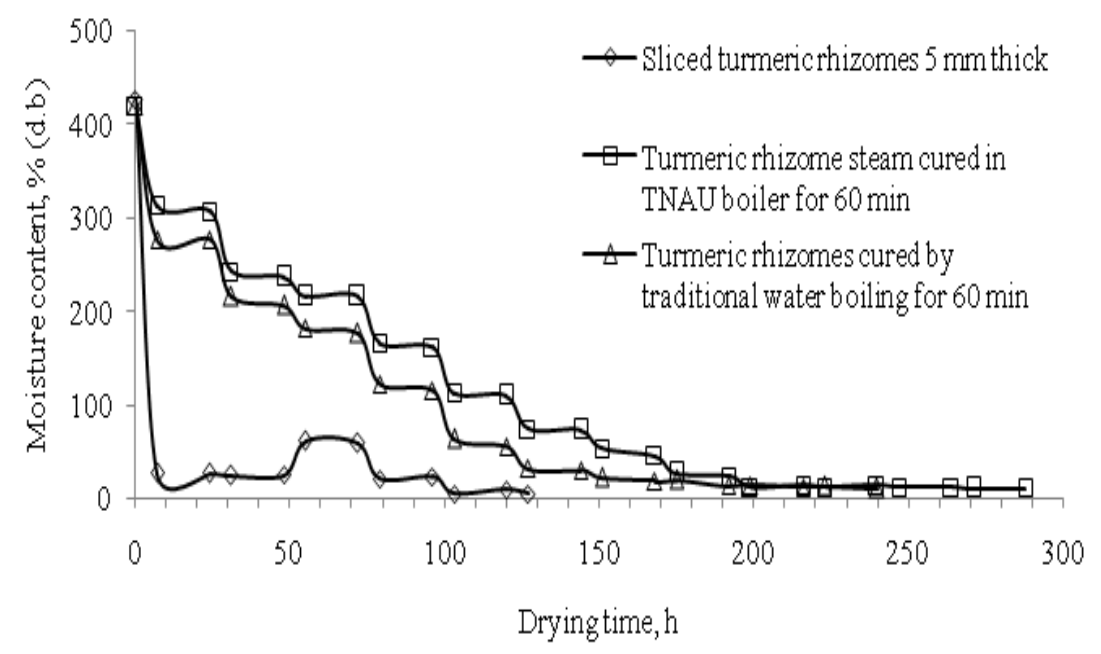

A

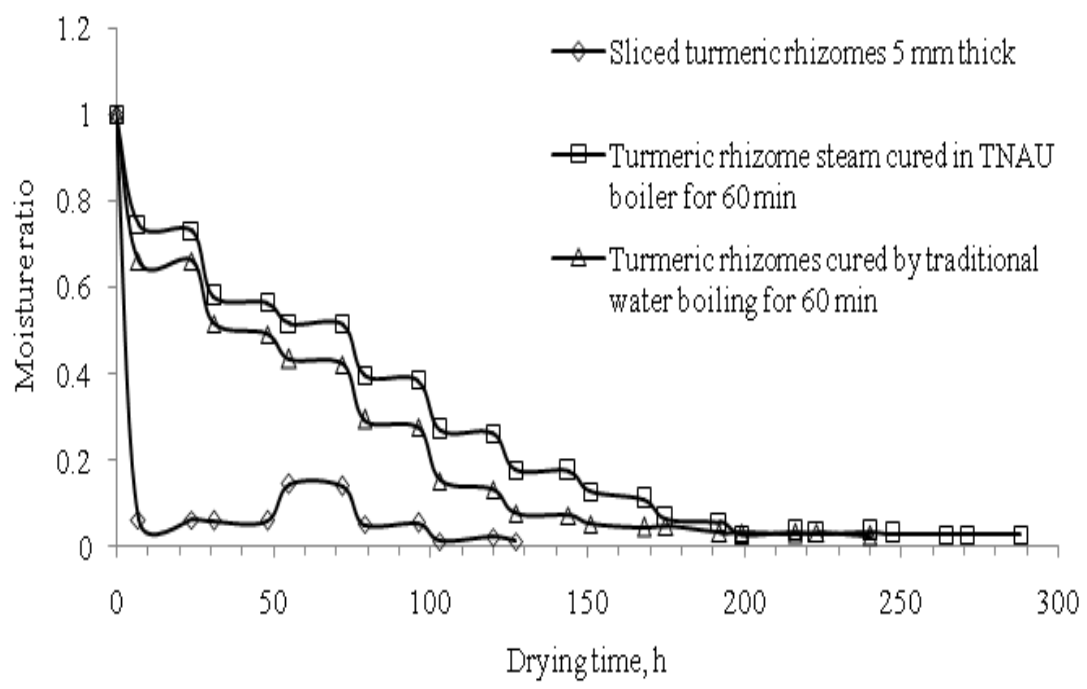

B

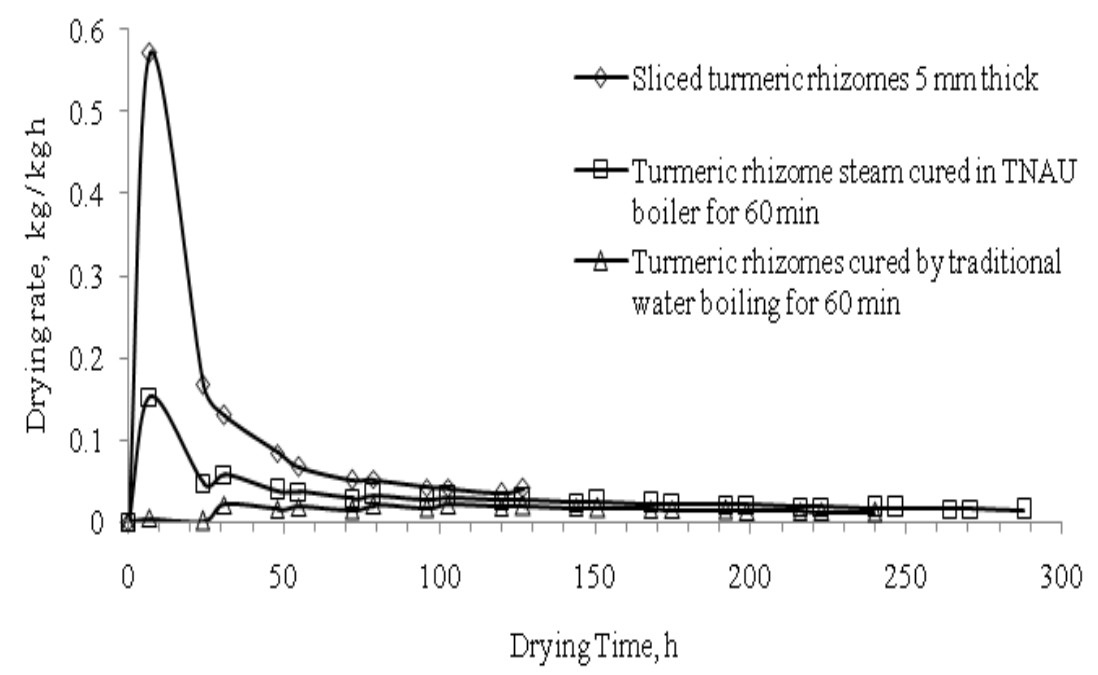

Fig. 1. Drying characteristics curves of sliced, steam cured and water cured turmeric.

(A) Moisture content versus drying time, (B) Moisture ratio versus drying time and (C) Drying rate versus drying time 
curcuminoids among the heat-treated samples. But, however, in the sun-dried samples, there was a significant reduction in curcuminoid concentration.

Lokhande et al. (2013) reported that the retention of curcumin was low in uncured samples than cured samples. Higher retention was observed in samples cured with improved method where the cleaned fingers were taken in perforated galvanized mild steel drums and immersed in a kettle containing alkaline solution $(0.1 \%$ Sodium bicarbonate) and boiled till the fingers became soft.

Jayashree \& Zachariah (2016) studied the effect of curing Prathiba variety of turmeric for various curing time of 30, 45 and 60 min by steam cooking in TNAU boiler and observed that with the increase in curing time there was significant reduction in curcumin content and maximum retention of the curcumin was obtained for turmeric cured for $30 \mathrm{~min}$.

\section{Variation in volatile oil constituents of essential oil}

Variation in constituents of volatile oil of turmeric as analysed by GC-MS indicated that maximum retention of ar-turmerone was obtained in sliced turmeric samples and the values corresponded to $43.75 \%$ and analysis of variance indicated that there was significant reduction of this constituent in turmeric samples cured by traditional water boiling and in turmeric samples steam cured in TNAU boiler (Table 4). However, the other constituents like the ar-curcumene, turmerone, $\beta$-sesquiphellandrene and $\alpha$ phellandrene showed no significant variations by following different curing methods.

Raina et al. (2002) reported that about 84 compounds were present in the oil of turmeric rhizomes obtained from North Indian Plains, of which the major compounds identified were eucalyptol $(11.2 \%), \alpha$ - turmerone $(11.1 \%), \beta$ caryophyllene $(9.8 \%)$, ar-turmerone $(7.3 \%)$ and $\beta$-sesquiphellandrene (7.1\%). Cousins et al., (2007) concluded that the chemical composition of the rhizome oil depends on the genotype, field conditions, and post harvest processing of turmeric. Gounder \& Lingamallu (2012) reported that the major constituents of volatile oil of turmeric were $\alpha$-turmerone (26.5-33.5\%), ar- turmerone (21.0-30.3\%), and $\beta$-turmerone (18.9$21.1 \%)$.

Pradeep et al. (2016) investigated the influence of blanching and drying methods on the quality of turmeric rhizomes and indicated that the quality of unblanched sliced rhizomes dried using hot air drier $\left(50 \pm 2^{\circ} \mathrm{C}\right.$ and $\left.58-63 \% \mathrm{RH}\right)$ was superior based on physico-chemical and colour values. The important constituents of the turmeric oil from blanched and unblanched rhizomes were tumerone, 61.54 and $62.91 \%$; curlone, 27.77 and $25.35 \%$; and cyclohexane, 1.73 and $1.32 \%$, respectively.

The study concluded that slicing significantly reduced the drying time to $127 \mathrm{~h}$. Turmeric rhizomes cured by traditional water boiling for $60 \mathrm{~min}$ took $240 \mathrm{~h}$ for complete drying. While turmeric rhizomes steam cured in TNAU turmeric boiler for $60 \mathrm{~min}$ took $288 \mathrm{~h}$ for complete drying. Maximum retention of primary metabolites was obtained in turmeric rhizomes cooked by water boiling method and maximum retention of secondary metabolites was obtained from sliced samples. Quality profiling of volatile oil of turmeric by GC-MS indicated that maximum retention of ar-turmerone in sliced turmeric samples and no significant variations was found in other constituents of turmeric during different processing methods.

\section{Acknowledgments}

The authors would like to acknowledge the support of the Director, ICAR-IISR and the staff members at IISR, Experimental farm, Peruvannamuzhi, Kozhikode for the support extended in carrying out the research work.

\section{References}

Asekun O T, Grierson D S \& Afolayan A J 2007 Effects of drying methods on the quality and quantity of the essential oil of Mentha longifolia L. subsp. Capensis. Food Chem. 101: 995-998.

ASTA 1968 Official Analytical Methods. second edition. American Spice Trade Association. New York: 53.

ASTA 1997 Official Analytical Methods, $2^{\text {nd }}$ edn. American Spice Trade Association, New Jersey. 
Borah A, Hazarika K \& Khayer S M 2015 Drying kinetics of whole and sliced turmeric rhizomes (Curcuma longa L.) in a solar conduction dryer. Information Processing in Agri. 2: 85-92.

Braga M E M, Leal P F, Carvalho J E \& Meireles M A A 2003 Comparison of yield, composition, and antioxidant activity of turmeric (Curcuma longa L.) extracts obtained using various techniques. J. Agri. Food Chem. 51: 6604-6611.

Chattopadhyay I, Biswas K, Bandyopadhyay U \& Banerjee R K 2004 Turmeric and curcumin: Biological actions and medicinal applications. Curr. Sci. 87: 44-53.

Cousins M, Adelberg J, Chen F \& Rieck J 2007 Antioxidant capacity of fresh and dried rhizomes from four clones of turmeric (Curcuma longa L.) grown in vitro. Ind. Crops Prod. 25: 129-135.

Esatbeyoglu T, Huebbe P, Ernst I M, Chin D, Wagner A E \& Rimbach G 2012 Curcumin-from molecule to biological function. Angewandte Chemie International Edition 51: 5308-5332.

Gounder D K \& Lingamallu J 2012 Comparison of chemical composition and antioxidant potential of volatile oil from fresh, dried and cured turmeric (Curcuma longa) rhizomes. Ind. Crops Prod. 38: 124-131.

Govindarajan V S \& Stahl W H 1980 Turmeric chemistry, technology and quality. CRC Crit. Rev. Food Sci. Nutr. 12: 199-301.

Jayashree E \& Zachariah T J 2016 Processing of turmeric by different curing methods and its effect on quality. Ind. J.Agrl. Sci. 86: 696-8.

Lokhande S M, Kale R V, Sahoo A K \& Ranveer R C 2013 Effect of curing and drying methods on recovery, curcumin and essential oil content of different cultivars of turmeric (Curcuma longa L.). Int. Food Res. J. 20: 745-749.

Peter K V 1999 Informatics on turmeric and ginger. Ind. Spices 36: 12-14.

Pradeep K, Ravi R, Jamuna Prakash \& Madhava Naidu M 2016 Influence of blanching and drying methods on the quality characteristics of fresh turmeric (Curcuma longa L.) rhizomes. Int. J. Appl. Pure Sci. Agri. 2(3): 32-44.

Prathapan A, Lukhman M, Arumughan C, Sundaresan A \& Raghu K G 2009 Effect of heat treatment on curcuminoid, colour value and total polyphenols of fresh turmeric rhizome. Int. J. Food Sci. Technol. 44: 1438-1444.

Raina V K, Srivastava, S K, Jain N, Ahmad A, Syamasundar K V \& Aggarwal K K 2002 Essential oil composition of Curcuma longa L., $\mathrm{cv}$. Roma from the plains of northern India. Flav. Frag. J. 17: 99-102.

Sadasivam S \& Manickam A 2008 Biochemical Methods for Agricultural Sciences $6^{\text {th }}$ Edn. New Age International (P) Ltd, New Delhi.

Spices Board 2017a Spices Board of India http:/ www.indianspices.com/statistics. accessed on 09-9-17.

Spices Board 2017b Annual Report 2015. http:// www.indianspices.com/sites/default/files/ Spices Board Annual Report 201516. Accessed on 6-09-2017.

Suresh D H, Manjunatha \& Krishnapura Srinivasa 2007 Effect of heat processing of spices on the concentrations of their bioactive principles: Turmeric (Curcuma longa), red pepper (Capsicum annum) and black pepper (Piper nigrum). J. Food Comp. Anal. 20: 346-51.

Viswanathan R, Devadas C T \& Sreenarayanan V V 2002 Farm level steam boiling of turmeric rhizomes. Spice India 15(7): 2-4. 